\title{
KESIAPSIAGAAN GURU SMAN 1 PRAMBANAN DALAM MENGHADAPI BENCANA GEMPA BUMI
}

\author{
Agustian Deny Ardiansyah ${ }^{1}$
}

Email: agustiandeny7@gmail.com

\begin{abstract}
Abstrak: Kesiapsiagaan dalam menghadapi bencana gempabumi merupakan salah satu usaha yang dilakukan untuk meningkatkan pengetahuan dan pemahaman masyarakat dalam menghadapi bencana gempabumi. Penelitian kesiapsiagaan guru SMA N 1 Prambanan dalam menghadapi bencana gempabumi bertujuan untuk menghasikan informasi mengenai pemahaman guru SMA $\mathrm{N} 1$ Prambanan tentang bencana gempabumi melalui cara berfikir ORID ( $O b$ jective, Refective, Interpretative, dan Decision) dan kesiapsiagaan guru SMA N 1 Prambanan dalam menghadapi bencana gempabumi melalui parameter pengetahuan dan sikap, rencana tanggap darurat, sistem peringatan bencana, mobilisasi sumber daya. Metode dalam penelitian ini adalah metode sensus dengan menggunakan pendekatan kuantitatif serta mengambil keseluruhan populasi guru SMA N 1 Prambanan yang berjumlah 55 orang sebagai responden. Pengumpulan data menggunakan dokumentasi dan quisioner dengan melakukan pengujian instrumen penelitian (kuisioner) melalui uji validitas dan realibilitas. Data dianalisa secara deskriptif kuantitatif dengan perhitungan persentase dan indeks. Hasil penelitian menyimpukan (1) pemahaman guru tentang bencana gempabumi relatif baik dengan jawaban yang cendrung mengarah pada jawaban sangat sesuai atau dengan persentase $83,81 \%$ dari $100 \%$ yang diharapkan (2) kesiapsiagaan guru SMA N 1 Prambanan dalam menghadapi bencana gempabumi dikategorikan siap dengan nilai indeks 71,9.
\end{abstract}

Kata Kunci : Bencana Gempabumi, ORID, Kesiapsiagaan Guru, Persentase, Indeks

\section{PENDAHULUAN}

Ancaman bencana alam di Indonesia merupakan refleksi kondisi geografis Indonesia yang terletak di tiga pertemuan lempeng aktif dunia, yaitu Lempeng Eurasia, Lempeng Indo-Australia, dan Lempeng Pasifik (Pribadi, 2008: 11). Interaksi antar lempeng lebih lanjut menempatkan Indonesia sebagai wilayah yang memiliki aktivitas kegunungapian dan kegempaan yang cukup tinggi. Interaksi antar lempeng juga mengakibatkan pembentukan relief permukaan bumi yang bervariasi, dari pegunungan dengan lereng yang sangat curam dan mengisaratkan ancaman bencana tanah longsor hingga wilayah landai sepanjang pantai dengan ancaman bencana banjir dan tsunami (Hartono, 2011: 1).

Kabupaten Klaten dalam kategori rawan bencana single hazard gempabumi menempati peringkat 2 Se-Kabupaten di Indonesia (Badan Nasional Penaggulangan Bencana, 2011: 158). Tingkat kerawanan bencana gempa bumi juga dibuktikan dengan peristiwa gempa bumi 27 Mei Tahun 2006 yang mengakibatkan 
Agustian Deny Ardiansyah. Kesiapsiagaan Guru SMAN 1 Prambanan Dalam Menghadapi Bencana Gempa Bumi

678 unit fasilitas pendidikan dan 26 unit fasilitas kesehatan rusak serta mengakibatkan 96.253 unit rumah warga rusak ringan, 63.615 unit rusak berat, dan 32.277 unit rumah roboh. Gempabumi 27 Mei Tahun 2006 juga menimbulkan korban luka sebayak 20.272 jiwa serta korban meninggal sebanyak 1.176 jiwa (Badan Penanggulangan Bencana Daerah Kabupaten Klaten, 2006: 1).

Kerusakan infrastruktur bangunan dan timbulnya korban jiwa juga terjadi pada warga sekolah dan sekolah, tercatat
73 orang meninggal, 33 cacat, 158 luka parah, dan 204 luka ringan. Dari jumlah tersebut terdapat 219 siswa (62 siswa meninggal, 22 siswa mengalami cacat, dan 135 siswa mengalami luka berat) serta 255 dari 306 sekolahan yang tersebar di Kecamatan Gantiwarno, Trucuk, Jogonalan, Cawas, Banyat, Wedi, dan Prambanan mengalami kerusakan (Koran Kompas edisi 12 Juli 2006). Berikut peta tingkat kerawanan bencana gempabumi di Kabupaten Klaten.

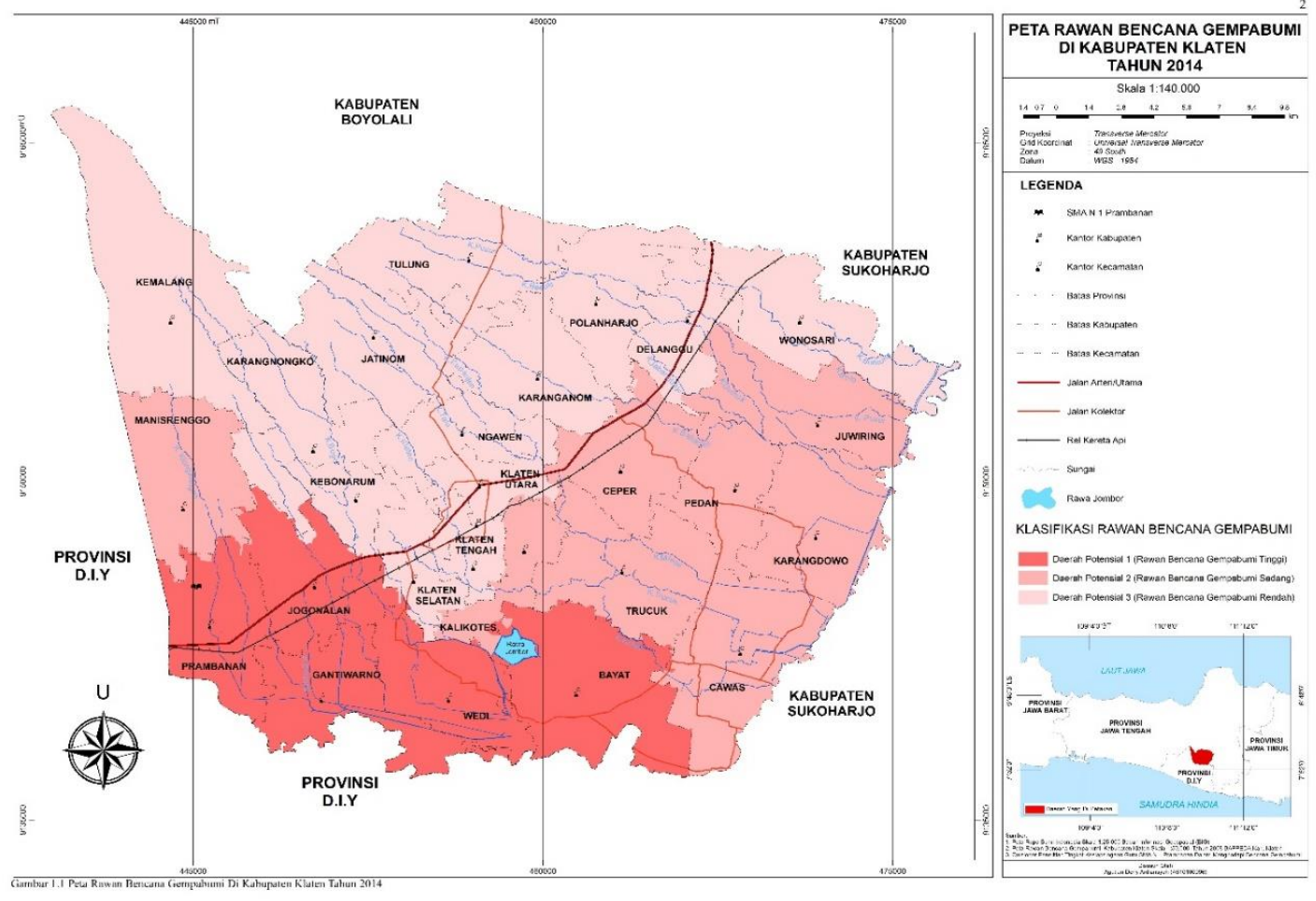

Gambar 1. Peta Rawan Bencana Gempabumi di Kabupaten Klaten

Secara geografis SMA N 1 Prambanan terletak pada $7^{\circ} 43^{\prime}$ 55.93"LS $110^{\circ} 30^{\prime} 7.62$ " BT dan secara administratif terletak di Jl. Manisrenggo-Prambanan, Desa Kebondalem Lor, Kecamatan
Prambanan, Kabupaten Klaten. Merefleksi letak SMA N 1 Prambanan yang berada di Kecamatan Prambanan, Kabupaten Klaten (daerah dengan kerawanan bencana gempabumi tinggi) dan kejadian 
bencana gempabumi 27 Mei Tahun 2006 dengan korban jiwa maupun kerusakan infrastruktur bangunan yang tidak sedikit, mengindikasikan SMA N 1 Prambanan memiliki ancaman bencana gempabumi yang sewaktu - waktu dapat terjadi.

Ancaman bencana gempabumi yang sewaktu-waktu dapat terjadi di SMA N 1 Prambanan perlu direspon oleh guru karena dapat menjadi sumber pemahaman tentang bencana, konsep bencana, wawasan bencana, dan tindakan kesiapsiagaan menghadapi bencana di lingkungan sekolah dengan melakukan upaya-upaya pengurangan resiko bencana gempabumi. Pertanyaannya, apakah guru telah memiliki pemahaman tentang bencana gempabumi dan kesiapsiagaan dalam menghadapi bencana gempabumi?.

Jufriadi (2012: 54) mengutip Lazan G.B dan Sarminto, pemahaman tentang bencana dapat didasarkan atas keutuhan dalam berfikir untuk memahami bencana atau khususnya resiko bencana melalui dinamika berfikir dan bertindak ORID (Objective, Reflective, Interpretative, and Decision). ORID dapat diungkapkan dengan proses mengingat kembali kejadian bencana dengan mempertimbangkan sejauh mana tingkat sensitivitas masyarakat dalam merespon bencana secara sensori (O), Sejauh mana tingkat reflektif masyarakat dalam menghayati pengalaman bencana atau membandingkan kondisi sebelum dan sesudah terjadi bencana, ketakutan, dan mungkin pengalaman masyarakat (R), kesadaran realitas yang dialami masyarakat dalam memahami pengaruh langsung maupun tidak langsung dari bencana terhadap masyarakat, keluarga, dan hal yang akan dilakukan di masa yang akan dating dalam menghada- pi bencana (I), dan kemauan masyarakat dalam membangun komitmen menghadapi bencana dan adaptasi terhadap berbagai perubahan yang terjadi akibat bencana (D).

Sopaheluwakan (2006: 146) menjelaskan, tingkat kesiapsiagaan masyarakat (individu) dalam menghadapi bencana dapat diukur dengan (1) pengetahuan dan sikap yang dimiliki masyarakat dalam membangun kemampuan terhadap ancaman atau potensi bencana secara cepat dan tepat guna, (2) rencana tanggap darurat yang disiapkan oleh masyarakat untuk melakukan tindakan cepat dan tepat guna pada saat terjadi bencana, (3) sistem peringatan bencana yang dilakukan masyarakat untuk membentuk suatu sistem peringatan bencana dalam rangka meningkatkan kemampuan dalam menghadapi bencana, dan (4) mobilisasi sumber daya yang dilakukan oleh masyarakat dalam menyiapkan sumber daya baik secara individu atau kolektif dalam rangka kesiapsiagaan menghadapi bencana.

Berdasarkan latar belakang masalah dan penjabaran kedua parameter penelitian di atas, menginspirasi peneliti untuk mengembangkan penelitian mengenai pemahaman tentang bencana dan tingkat kesiapsiagaan masyarakat (individu) dalam menghadapi bencana dengan objek penelitian guru SMA N 1 Prambanan. Hal tersebut dilakukan peneliti untuk mengetahui pemahaman guru SMA N 1 Prambanan tentang bencana gempabumi dan tingkat kesiapsiagaan guru SMA N 1 Prambanan dalam menghadapi bencana gempabumi dengan mengambil judul penelitian "Kesiapsi- 
Agustian Deny Ardiansyah. Kesiapsiagaan Guru SMAN 1 Prambanan Dalam Menghadapi Bencana Gempa Bumi

agaan Guru SMA N 1 Prambanan dalam Menghadapi Bencana Gempabumi'.

\section{METODE PENELITIAN}

Metode dalam penelitian ini menggunakan metode sensus dengan mengambil semua populasi guru SMA N 1 Prambanan yang berjumlah 55 orang sebagai responden. Pengumpulan data dilakukan menggunakan dokumentasi dan kuisioner dengan melakukan pengujian instrumen penelitian (kuisioner) melalui uji validitas dan realibilitas.

Dokumentasi digunakan untuk mengkaji data sekunder yang meliputi profil SMA N 1 Prambanan, data guru SMA N 1 Prambanan, data kerusakan infrastruktur bangunan SMA N 1 Prambanan akibat gempabumi 27 Mei Tahun 2006, dan untuk mendapatkan data kerusakan maupun korban jiwa akibat gempabumi 27 Mei Tahun 2006 di Kecamatan Prambanan dari Badan Penanggulangan Bencana Daerah Kabupaten Klaten.

Sedangkan kuisioner digunakan untuk mengukur pemahaman guru SMA N 1 Prambanan tentang bencana gempabumi melalui parameter Objective, Reflective, Interpretative, and Decision dengan menggunakan skala pengukuran Likert yang memiliki gradasi jawaban Tidak Sesuai (TS) skor 1, Kurang Sesuai (KS) skor 2, Sesuai (S) skor 3, dan Sangat Sesuai (SS) skor 4.

Selain untuk mengukur pemahaman, kuisioner juga digunakan untuk mengukur tingkat kesiapsiagaan guru SMA N 1 Prambanan dalam menghadapi bencana gempabumi melalui parameter sikap dan pengetahuan, rencana tanggap darurat, sistem peringatan bencana serta mobilisasi sumber daya dengan menggunakan skala pengukuran Guttman yang memiliki opsi jawaban YA skor 1 dan TIDAK skor 0 .

Data hasil penyadapan melalui kuisioner yang telah melalui uji validitas dan realibilitas kemudian diubah menjadi data kuantitatif dalam bentuk skor dan dianalisis secara deskriptif kuantitatif dengan perhitungan persentase dan indeks. Perhitungan dalam bentuk persentase digunakan untuk menyampaikan pemahaman guru SMA N 1 Prambanan tentang bencana gempabumi dengan kategori tidak sesuai, kurang sesuai, sesuai, dan sangat sesuai dalam bentuk presentase (0-100\%) sehingga semakin tinggi nilai presentase, maka kecenderungan pemahaman guru tentang bencana gempabumi semakin baik.

Perhitungan indeks digunakan untuk menyampaikan tingkat kesiapsiagaan guru SMA N 1 Prambanan dalam menghadapi bencana gempabumi dengan kategori tidak siap nilai indeks (0-39), kurang siap nilai indeks (40-45), hampir siap nilai indeks (55-64), siap nilai indeks (65-79), dan sangat siap nilai indeks (80100) sehingga semakin tinggi nilai indeks, maka tingkat kesiapsiagaan guru dalam menghadapi bencana gempabumi semakin tinggi. Berikut diagram alir penelitian ini. 


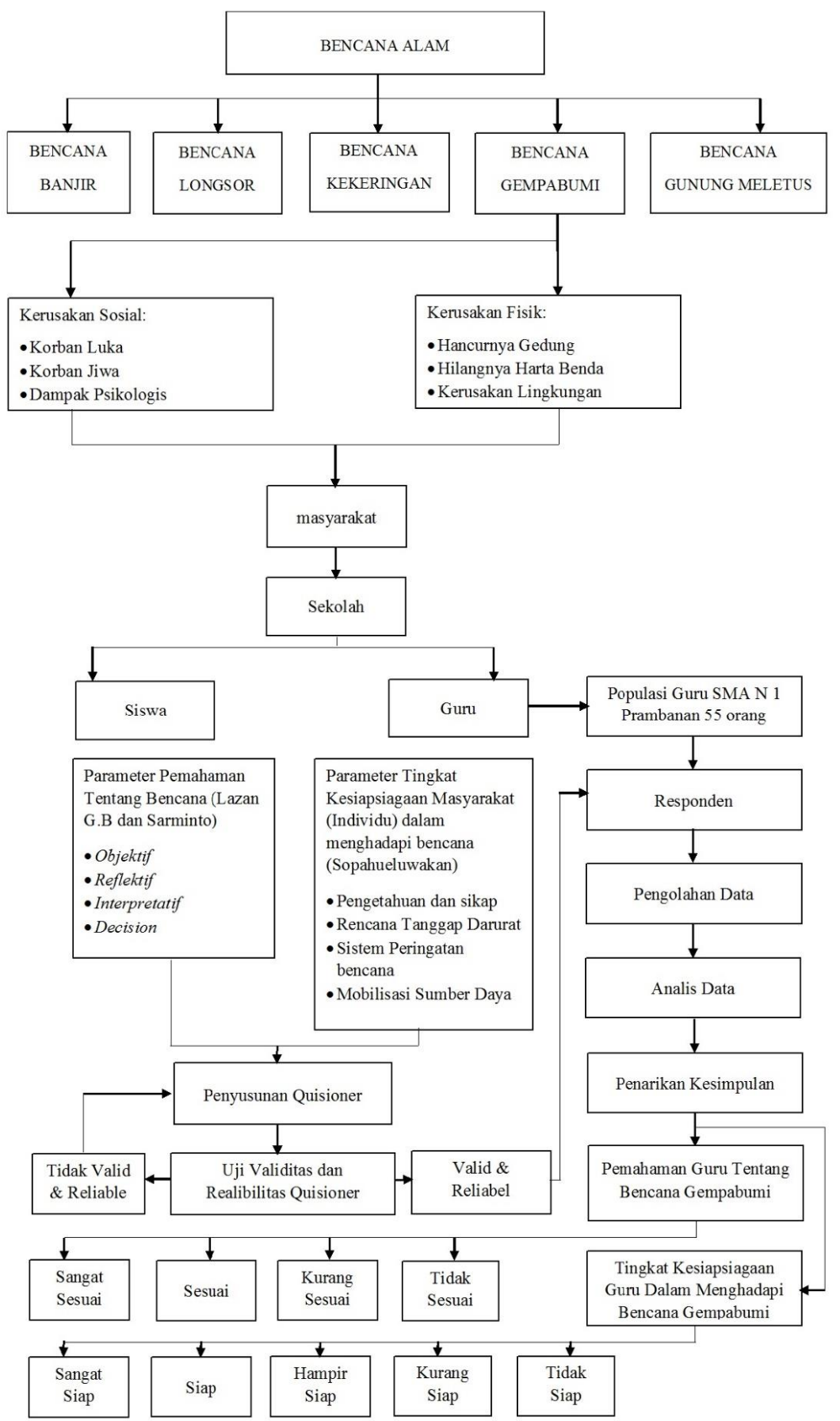

Gambar 2. Diagram Alir Penelitian 
126

Agustian Deny Ardiansyah. Kesiapsiagaan Guru SMAN 1 Prambanan Dalam Menghadapi Bencana Gempa Bumi

\section{HASIL PENELITIAN}

\section{Dampak gempabumi 27 Mei 2006}

SMA N 1 Prambanan terletak di Jalan Manisrenggo - Prambanan, Desa Kebondalem Lor, Kecamatan Prambanan, Kabupaten Klaten. Kecamatan Prambanan merupakan salah satu kecamatan yang berada di Kabupaten Klaten dengan batas administratif sebelah barat berbatasan dengan Kecamatan Prambanan (DIY), sebelah timur berbatasan dengan Kecamatan Jogonalan, Sebelah utara berbatasan dengan Kecamatan Manisrenggo dan sebelah selatan berbatasan dengan Kecamatan Gantiwarno (BAPPEDA Kabupaten Klaten, 2012: 5).

Kecamatan Prambanan terdiri atas 16 Desa/Kelurahan dan menempati wilayah seluas $24.43 \mathrm{~km} 2$ serta memiliki jumlah penduduk 41.789 jiwa dengan kepadatan penduduk 1.711 per $\mathrm{Km} 2$ (tergolong sedang). Kecamatan Prambanan memiliki karakteristik topografi dengan ketinggian 100-200 mdpal. Sarana Pendidikan di lingkup Kecamatan Prambanan terdiri atas, 32 SD/MI, 3 SMP/MTS, 2 SMA/MA negeri serta 30 TK, 1 SD/MI, 1 SMP/MTS, 1 SMA/MA, dan 1 SMK swasta (BAPPEDA Kabupaten Klaten, 2012: 10).
Kecamatan Prambanan dalam gempabumi 27 Mei Tahun 2006 merupakan salah satu kecamatan di Kabupaten Klaten yang terkena dampak akibat gempabumi. Badan Penanggulangan Bencana Daerah Kabupaten Klaten mencatat dampak kerusakan dan kerugian gempabumi 27 Mei Tahun 2006 sebanyak 4.252 unit rumah warga rusak berat, 3.149 unit rumah warga rusak ringan serta 4.034 rumah warga rusak total dan warga meninggal sebanyak 221 jiwa yang tersebar di 16 Desa/Kelurahan di Kecamatan Prambanan.

SMA N 1 Prambanan juga mengalami kerusakan dengan 6 kelas rusak berat dan 1 laboraturium bahasa tidak bisa digunakan akibat tembok roboh. Berikut peta kerusakan rumah warga akibat gempabumi 27 Mei 2006 di Kecamatan Prambanan Kabupaten Klaten dan kerusakan bangunan SMA N 1 Prambanan. 


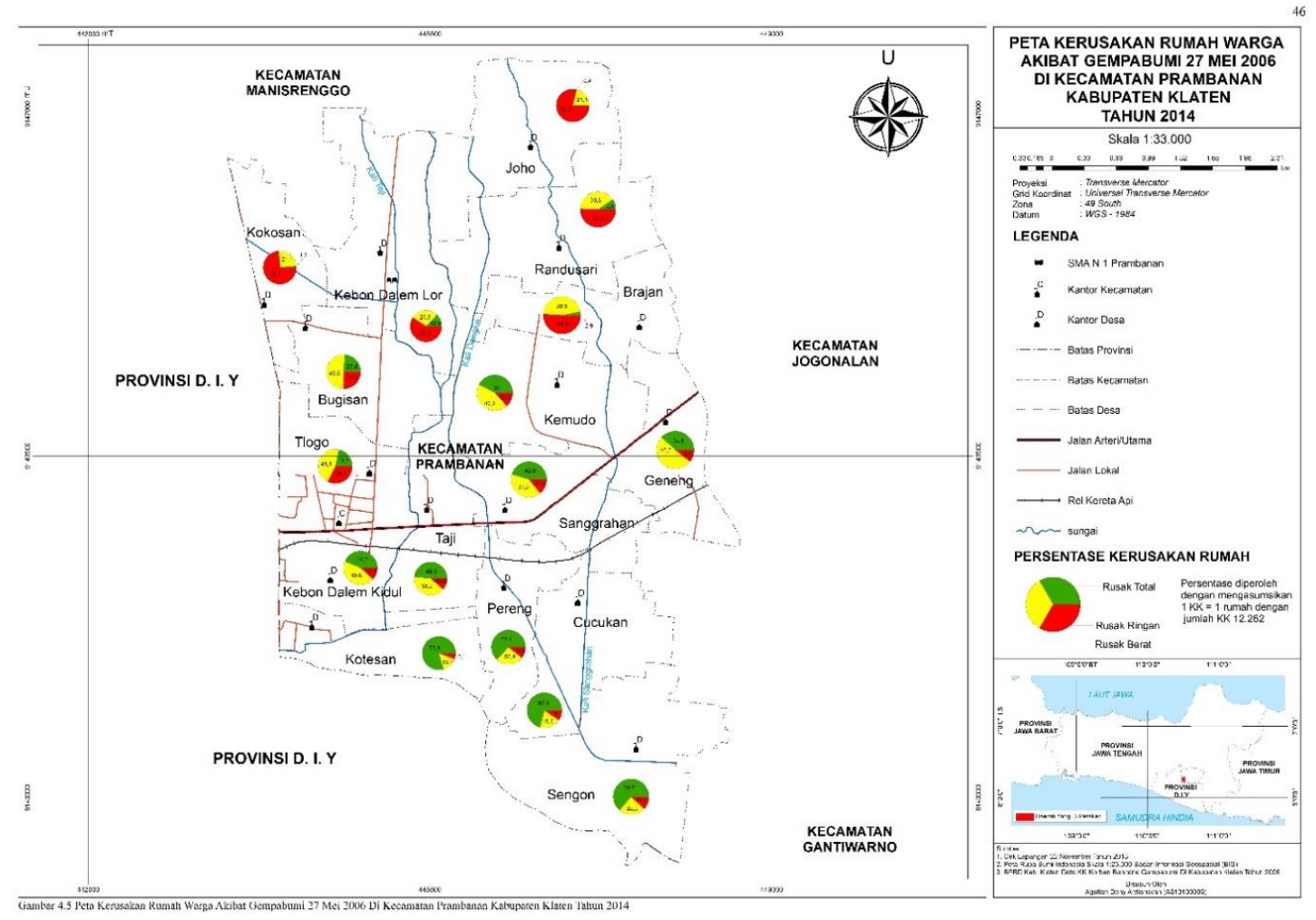

Gambar 3. Peta Kerusakan Rumah Warga Akibat Gempabumi 27 Mei 2006 Di Kec. Prambanan
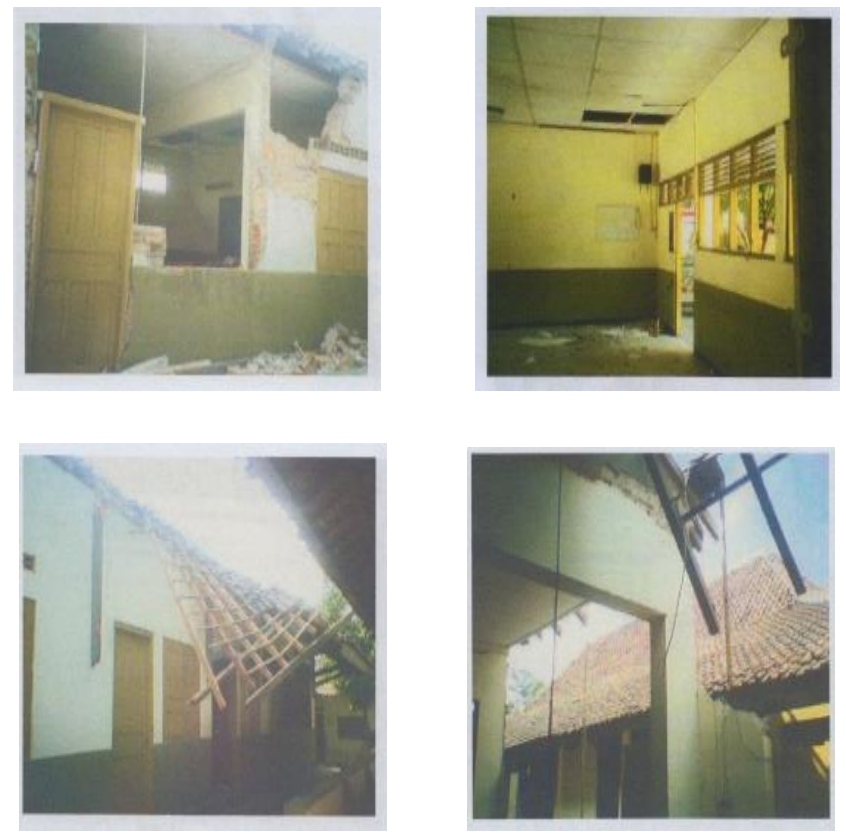

Gambar 4. Kerusakan SMA 1 Prambanan Akibat Gempa 2004 


\section{Pemahaman Guru SMA N 1 Prambanan Tentang Bencana Gempabumi}

Pemahaman guru SMA N 1 Prambanan tentang bencana gempabumi berdasarkan data yang disadap melalui kuisioner menunjukan pemahaman yang relatif baik dengan jawaban cendrung sangat sesuai. Kecendrungan jawaban sangat sesuai juga dibuktikan oleh persentase pemahaman guru SMA N 1 Prambanan tentang bencana gempabumi dengan $83,81 \%$ dari $100 \%$ yang diharapkan. Berikut perhitungan pemahaman guru SMA N 1 Prambanan tentang bencana gempabumi.

$$
\begin{aligned}
& \begin{aligned}
\text { Jumlah }= & \text { Objective }+ \text { Reflective }+ \text { Interpretative }+ \text { Decision } \\
& =1317+1428+755+1101 \\
& =4601
\end{aligned} \\
& \begin{aligned}
\text { Kriteria }= & \frac{\text { Nilai Tertigi Gradasi } \times \text { Jumlah Soal } \times \text { Jumlah Responden }}{\text { Nilai Tertinggi Gradasi }} \\
= & \frac{4 \times 25 \times 5}{4} \\
= & 5500 / 4 \\
= & 1375
\end{aligned} \\
& \begin{aligned}
\text { Persentase } & =\frac{\text { Nilai Riil Parameter }}{\text { Nilai Maksiaml }} \times 100 \% \\
& =4610 / 5500 \times 100 \% \\
& =83,81 \%
\end{aligned}
\end{aligned}
$$

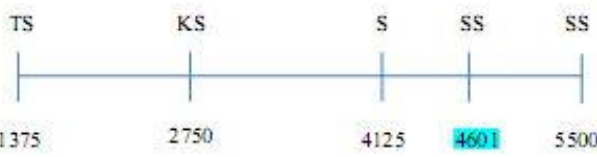

Pemahaman guru SMA N 1 Prambanan tentang bencana gempabumi selain didasarkan atas perhitungan kolektif, juga didasarkan pada perhitungan prosentase menurut mata pelajaran yang diampu (guru geografi dan mapel lain), berdasarkan kerawan bencana gempabumi tempat tinggal, (rendah, sedang, dan tinggi) dan berdasarkan jenis kelamin (laki-laki dan perempuan).

Perhitungan persentase berdasarkan mata pelajaran yang diampu (guru geografi dan mapel lain) didapatkan pemahaman guru tentang bencana gempabumi relatif baik dengan jawaban cenderung sangat sesuai. Kecendrungan jawaban sangat sesuai juga dibuktikan oleh persentase jawaban guru geografi $86 \%$ dan guru mapel lain $83,56 \%$ dari $100 \%$ yang diharapkan. $82,45 \%$, tingkat kerawanan sedang $90 \%$, dan tingkat kerawanan tinggi $83,51 \%$ dari $100 \%$ yang diharapkan.

Perhitungan persentase berdasarkan jenis kelamin didapatkan pemahaman guru tentang bencana gempabumi relatif baik dengan kecenderungan jawaban sangat sesuai. Kecenderungan jawaban sangat sesuai juga dibuktikan oleh persentase jawaban guru laki-laki 82,61\% dan guru perempuan $84,25 \%$ dari $100 \%$ yang diharapkan. 
Tingkat Kesiapsiagaan Guru SMA N 1 Prambanan Dalam Menghadapi

\section{Bencana Gempabumi}

Tingkat kesiapsiagaan guru SMA N 1 Prambanan dalam menghadapi bencana gempabumi berdasarkan data yang disadap melalui kuisioner menunjukan tingkat kesiapsiagaan guru pada kategori siap dengan nilai indeks 71,9. Nilai indeks 71,9 tersebut didasarkan pada akumulasi skor kesiapsiagaan 55 re-

$$
\begin{aligned}
\text { Indeks } & =\frac{\text { Total skor riil per parameter }}{\text { skor maksimum per parameter }} \times 100 \\
& =\frac{179,25+436+256+236}{28 \times 55} \times 100 \\
& =\frac{1107,25}{1540} \times 100 \\
& =71,9 \text { (Siap) }
\end{aligned}
$$

Tingkat kesiapsiagaan Guru SMA N 1 Prambanan dalam menghadapi bencana gempabumi selain didasarkan atas perhitungan kolektif, juga didasarkan pada perhitungan indeks menurut mata pelajaran yang diampu (guru geografi dan mapel lain), berdasarkan kerawan bencana gempabumi tempat tinggal, (rendah, sedang, dan tinggi) dan berdasarkan jenis kelamin (laki-laki dan perempuan).

Tingkat kesiapsiagaan guru yang didasarkan atas mata pelajaran yang diampu, dalam penelitian ini membedakan sponden (guru) per parameter pengetahuan dan sikap, rencana tanggap darurat, sistem peringatan bencana dan mobilisasi sumber daya dengan kategori sangat siap sebanyak 20 orang (36\%), siap 11 orang (20\%), hampir siap 17 orang (31\%), kurang siap 7 orang (13\%) dan belum siap 0 orang (0\%). Berikut perhitungan indeks dan grafik tingkat kesiapsiagaan guru SMA N 1 Prambanan dalam menghadapi bencana gempabumi.

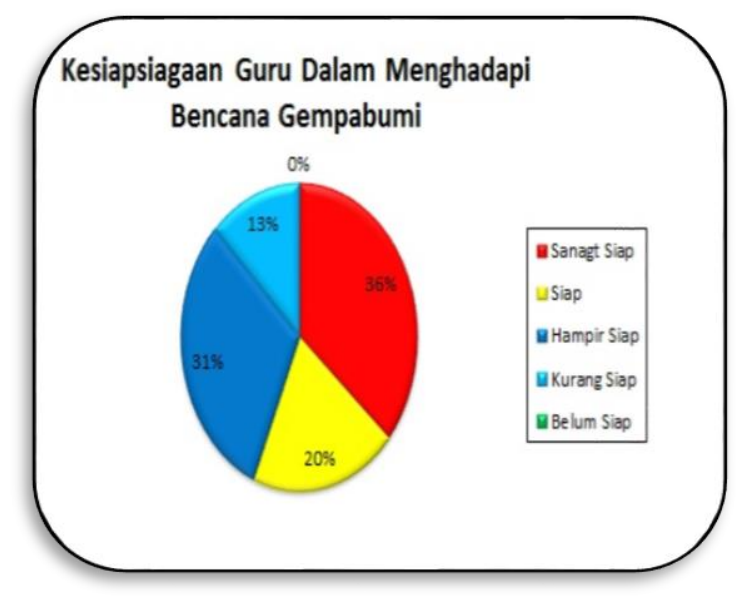

Gambar 5. Grafik Tingkat Kesiapsiagaan Guru SMA N 1 Prambanan dalam Menghadapi Bencana Gempabumi

guru yang mengajar mata pelajaran geografi dan mata pelajaran lain. Hasil penelitian memperlihatkan tingkat kesiapsiagaan guru dalam menghadapi bencana gempabumi masuk dalam kategori siap. Hal itu dibuktikan dengan nilai indeks guru geografi 65,1 (siap) dan nilai indeks mapel lain adalah 72,1 (siap).

Tingkat kesiapsiagaan guru yang didasarkan atas tingkat kerawanan bencana gempabumi tempat tinggal memiliki perbedaan nilai indeks antara tingkat bencana gempabumi kerawanan rendah, sedang, dan tinggi. Perbedaan 
130

Agustian Deny Ardiansyah. Kesiapsiagaan Guru SMAN 1 Prambanan Dalam Menghadapi Bencana Gempa Bumi

tersebut terlihat dari nilai indeks daerah dengan tingkat kerawanan rendah 66,23 (siap), daerah kerawanan sedang nilai indeks 53,71 (kurang siap), dan daerah kerawanan tinggi nilai indeks 74,51 (siap).

Tingkat Kesiapsiagaan guru yang didasarkan atas jenis kelamin dalam penelitian ini membedakan guru laki-laki dan. Hasil penelitian memperlihatkan tingkat kesiapsiagaan guru berdasarkan jenis kelamin masuk dalam kategori siap. Tingkat Kesiapsiagaan tersebut juga dibuktikan dengan nilai indeks guru lakilaki 72,36 (siap) dan nilai indeks guru perempuan 69,79 (Siap).

\section{Hubungan Pemahaman Guru SMA N \\ 1 Prambanan Tentang Bencana gempabumi dan Tingkat \\ Kesiapsiaggan Guru SMA N 1 \\ Prambanan Dalam Menghadapi \\ Bencana Gempabumi}

Hasil perhitungan menunjukan nilai pemahaman guru SMA N 1 Prambanan tentang bencana gempabumi dan tingkat kesiapsiagan guru SMA N 1 Prambanan dalam menghadapi bencana gemapbumi memiliki nilai signifikan $0,542>0,05$. Hal tersebut menunjukan, antara pemahaman guru SMA N 1 Prambanan tentang bencana gempabumi dan tingkat kesiaspsiagaan Guru SMA N 1 Prambanan dalam menghadapi bencana gempabumi memiliki hubungan yang linier karena nilai probabilitas $>0,05$.

Selain menunjukan tingkat hubungan yang linier, pemahaman guru SMA N 1 Prambanan tentang bencana gempabumi dan tingkat kesiapsiagaan guru SMA N 1 prambanan dalam menghadapi bencana gempabumi juga dapat menunjukan tingkat keberatian. Keberatian tersebut dikatakan berarti jika nilai probabilitas < 0,05 .

Hasil perhitungan menunjukan nilai probabilitas pemahaman guru SMA N 1 Prambanan tentang bencana gempabumi dan tingkat kesiapsiagan guru SMA N 1 Prambanan dalam menghadapi bencana gemapbumi memiliki Fhitung 0,360 dan signifikan 0,554>0,05. Hasil pehitungan tersebut dapat disimpulkan antara pemahaman dan tingkat kesiapsiagaan tidak memiliki tingkat keberartian yang berarti.

Dari perhitungan di atas dapat disimpulkan hubungan antara pemahaman guru SMA N 1 Prambanan tentang bencana gempabumi dan tingkat kesiapsiagaan guru SMA N 1 Prambanan dalam menghadapi bencana gempabumi memiliki hubungan yang linier namun tidak memiliki tingkat kebertian yang berarti. 


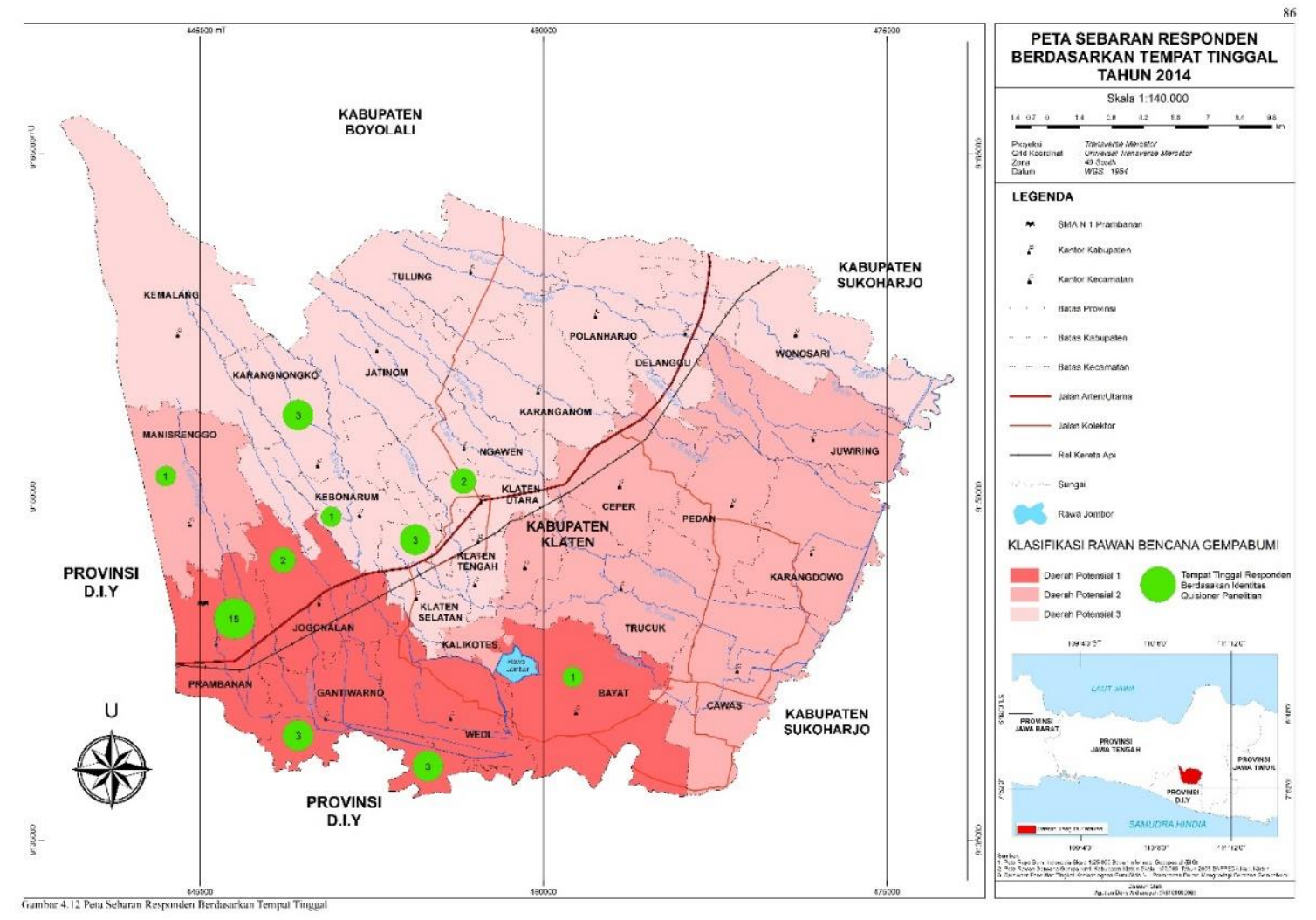

Gambar 6. Peta Sebaran Responden Berdasarkan Tempat Tinggal Tahun 2014

\section{Tingkat Kesiapsiagaan Guru SMA N 1 Prambanan dalam Menghadapi Bencana Gempabumi}

Hasil penelitian menunjukan tingkat kesiapsiagaan guru SMA N 1 Prambanan dalam menghadapi bencana gempabumi dikategorikan siap dengan nilai indeks 71,9. Hasil tersebut didasarkan pada tingkat kesiapsiagaan guru pada parameter pengetahuan dan sikap, rencana tanggap darurat, sistem peringatan bencana, serta mobilisasi sumber daya.

Parameter pengetahuan dan sikap memiliki nilai indeks 81,47 dengan kategori sangat siap. Hal tersebut didasarkan pada 48 responden menyatakan lingkungan sekolah tempat berkerja memiliki potensi bencana gempabumi yang sewaktu-waktu dapat terjadi dan 43 responden pernah menginformasikan tentang tindakan dan peralatan yang perlu disiapkan sebelum terjadi gempabumi.

Parameter rencana tangga darurat memiliki nilai indeks 72,06 dengan kategori siap. Hal tersebut didasarkan pada 50 responden yang menyatakan menggunakan laptop/komputer untuk menyimpan dokumen yang berkaitan dengan data penilaian akademik peserta didik dan materi pembelajaran dan 46 responden menyatakan akan menggunakan P3K dan atau tandu untuk melakukan pertolongan pertama jika sewaktu-waktu terjadi bencana gempabumi di sekolah. 
Parameter sistem peringatan dini memiliki nilai indeks 77,57 dengan kategori siap. Hal tersebut didasarkan pada 41 responden yang menyatakan mendapat penyuluhan tentang sumber informasi bencana gempabumi, misal; kentongan, sirine, atau bel, 51 responden sering melihat dan membaca berita baik melalui media cetak atau elektronik tentang informasi bencana dan peringatan bencana, 53 responden akan segera menginformasikan kepada kepada peserta didik dan atau warga sekolah jika sewaktu-waktu ada informasi peringatan bencana, dan 37 responden pernah mengikuti kegiatan simulasi bencana gempabumi baik dilingkungan sekolah maupun masyarakat dengan menggunkan kentongan serta sirine setelah gempabumi 27 Mei 2006.

Parameter mobilisasi sumber daya memiliki nilai indeks 61,29 dengan kategori hampir siap. Hal tersebut didasarkan pada 26 responden tidak pernah terlibat dalam kegiatan penanggulangan bencana baik di sekolah atau masyarakat dan 29 responden menyatakan tidak memiliki buku bacaan, modul, powerpoint, video, dan atau gambar yang dapat memberikan informasi tentang gempabumi atau kesiapsiagaan dalam menghadapi bencana gempabumi.

Indeks kesiapsiaggan guru SMA N 1 prambanan dalam menghadapi bencana gempabumi yang menunjukan tingkat kesiapsiaggan guru siap dengan nilai indeks 71,9 juga didasarkan pada dukungan pihak sekolah dalam meningkatkan kesiapsiagaan menghadapi bencana gempabumi. Hal tersebut tercermin dari adanya sarana dan prasarana sekolah seperti pamflet atau majalah diding yang memuat tentang pendidikan kesiapsi- agaan dalam menghadapi bencana gempabumi, penyediaan kotak P3K (tas siaga bencana), tandu, tenda, kain kasa, dan obat-obatan.

Dukungan pihak sekolah dalam kesiapsiagaan menghadapi bencana gempbumi juga ditunjukan dalam pengecekan struktur bangunan SMA N 1 Prambanan oleh TIM Assesment Teknik Sipil UGM, pemisahan struktur bangunan sekolah, pembuatan jalur evakuasi, dan penyedian tempat berkumpul (shelter). Berikut sarana dan prasarana sekolah dalam meningkatkan kesiapsiagaan menghadapi bencana gempabumi. 

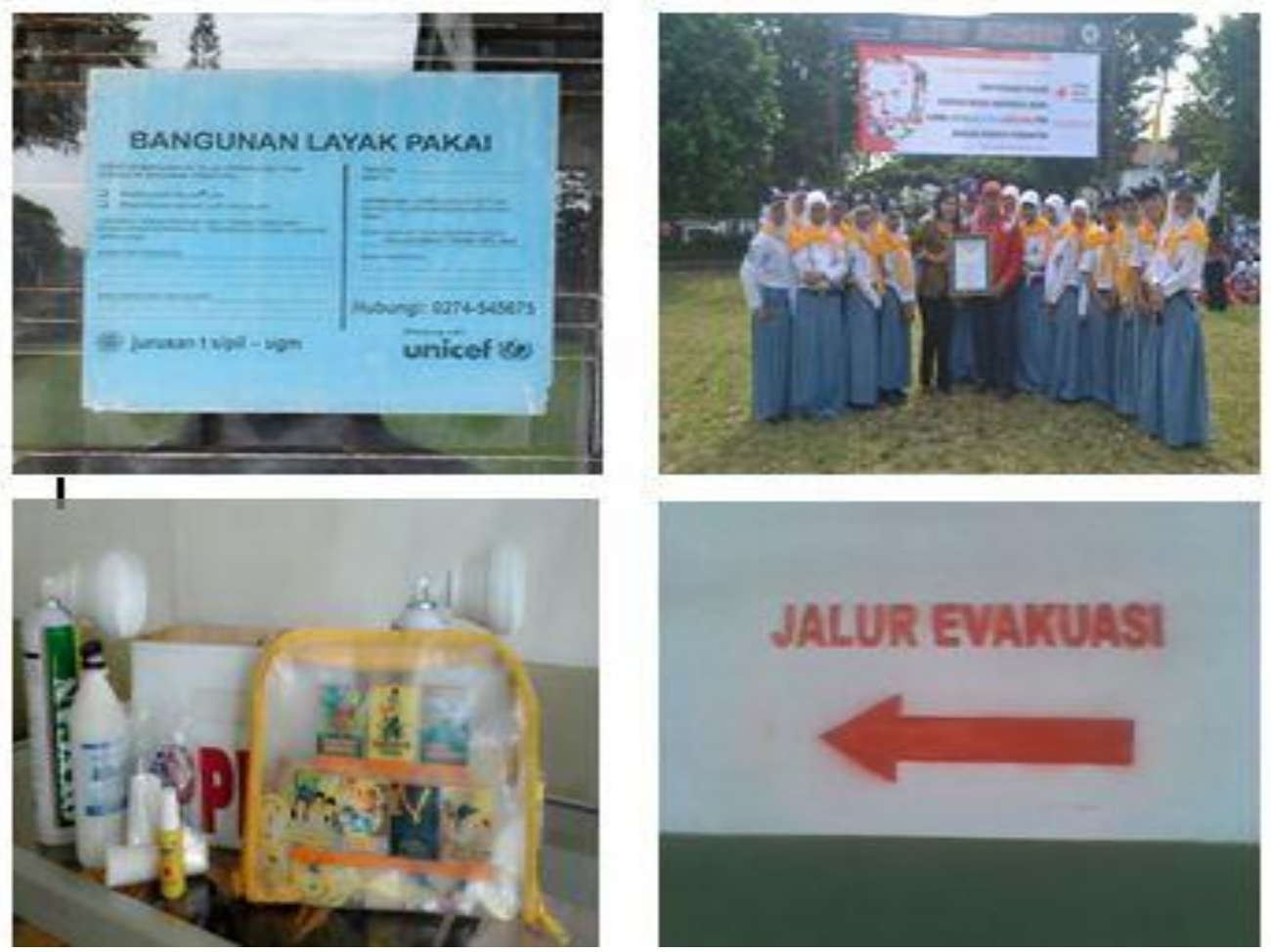

Gambar 7. Sarana dan Prasarana Sekolah dalam Kesiapsiagan Menghadapi Bencana Gempabumi

\section{KESIMPULAN}

Berdasarkan hasil penelitian dan pembahasan di atas, dapat disimpulkan bahwa pemahaman guru SMA Tentang bencana gempabumi dapat dikategorikan relatif baik dengan jawaban cendrung sangat sesuai dengan persentase $83,81 \%$ dari $100 \%$ yang diharapkan dan tingkat kesiapsiagaan guru SMA N 1 Prambanan dalam menghadapi bencana gempabumi dikategorikan siap dengan nilai indeks 71,9 .

\section{DAFTAR RUJUKAN}

Badan Nasional Penanggulangan Bencana. 2011. Indeks Rawan Bencana Indonesia 2011. Jakarta:
Badan Nasional Penanggulangan Bencana.

Badan Penanggulangan Bencana Daerah Kabupaten Klaten. 2006. Data Kerusakan Dan Korban Meninggal Akibat Gempabumi 27 Mei Tahun 2006. Klaten: Badan Penanggulangan Bencana Daerah Kabupaten Klaten.

BAPPEDA Kabupaten Klaten. 2012. Klaten Dalam Angka 2012. Klaten. BAPPEDA Kabupaten Klaten.

Hartono. 2011. Kesiapsiagaan Masyarakat Dalam Menghadapi Bencana Gempabumi Di Kecamatan Pangalengan Kabupaten Bandung. Skripsi tidak diterbitkan. Bandung: FPIPS 
134

Agustian Deny Ardiansyah. Kesiapsiagaan Guru SMAN 1 Prambanan Dalam Menghadapi Bencana Gempa Bumi

Pendidikan Geografi Universitas Pendidikan Indonesia.

Jufriadi, Akhmad, dkk. 2012. Sosialisasi

"Penguranagan Resiko Bencana"

Di Kecamatan Tempursari

Kabupaten Lumajang Sebagai

Upaya Pendidikan Mitigasi

Bencana. Jurnal ERUDIO. Vol 1.

No. 1 Desember 2012: 50-58.

Kompas. 12 Juli 2006. " Pasca gempa 225 Sekolah Rusak, Guru dan Murid Cacat", hal 12.

Pribadi, S, Krisna, dkk. 2008. Buku Pegangan Guru Pendidikan Siaga Bencana. Bandung: Pusat Mitigasi Bencana - ITB.

Sopaheluwakan, dkk. 2006. Kajian Kesiapsiagaan Masyarakat Dalam Mengantisipasi Bencana Gempabumi dan Tsunami. Jakarta: LIPI-UNESCO/ISD. 